\title{
RESOURCES OF THE MUSLIM WORLD: A REFFLECTION ON THE MUSLIM WORLD'S RESOURCES, THEIR DEVELOPMENT AND UTILIZATION
}

\author{
Dr. Muhammad Iqbal Majoka \\ Mr. Habib Elahi Sahibzada \\ Dr. Muhammad Saeed Khan
}

\begin{abstract}
Natural resources, infrastructure and human resources play an important role in the development of a country. It is a worldwide proven fact that the development of a nation depends on availability of natural resources $(24 \%)$, infrastructure $(16 \%)$ and human resources that add $60 \%$. In the present sociopolitical and economic scenario of the world, the block of Muslim countries is recognized as developing or under developed despite being rich in the natural resources on the Earth as well as being blessed with abundant human resources. This paper gives a full reflection of natural resources, infrastructure and human resources of the Muslim world as compared to the rest of the world. It highlights the root causes for the prevalent miserable state of the Muslim Ummah. It also presents a model for the training, retraining and development of human resources of the Muslim world as a remedial measure to stand as part of the developed world.
\end{abstract}

Keywords: Natural Resources, Muslim, Model, Civilization

\section{INTRODUCTION}

We are living in a world in which various sects, social groups, and nations are in a hard competition for the survival of the fittest. In the history of the world, there have been numerous civilizations that sustained their identity until they were able to survive. This survival was based on sound foundations of socio-cultural values as well as quantitative strength in terms of natural resources under use, infrastructure for various developmental activities and productive manpower. At present, two main civilizations, 'The West,' and 'The Muslim World,' have emerged under the hypocritical idea of 'the clash of civilizations'. The first civilization is availing its glorious period with enormous strategic power and tremendous economic strength. The Muslim world, despite having the most practical set of socio-cultural values, 
abundance of both natural and human resources, supplemented by various races, colors, and diverse cultures, is being plummeted by the West. The intellectuals of the Muslim community are very conscious of this dreadful condition. Therefore, there are calls and voices for diagnosis of the grassroot causes of this dilemma and recommendations for practical remedial steps. One of the outstanding challenging aspects of this Muslim world dilemma is related to economics. Prof. M. M. Sharif ${ }^{1}$ has highlighted an Islamic principle of economy by saying, "the first economic principle emphasized by the Quran with repeated stress is that all natural means of production and resources which subscribe to man's living, have been created by God. It is He who made them to follow the laws of nature that make them useful for man".

\section{HISTORICAL BACKGROUND}

A panoramic view of the Muslim world reveals that at the time of its prime, Muslims were the leaders and torch-bearers for the rest of humanity, regarding what is called culture and civilization. Islam, since her very inception, expanded from a mere religion to a state, and then as an established civilization. In the words of P. K. Hitti $^{2}$ (1970), "originally a religion, Islam later became a state, and finally a culture".

The question is, what was the steering force behind that remarkable civilization? The answer lies, no doubt, in the strong belief system and the practicality of knowledge with which the Muslims were endowed. Regarding this, Al Faruqi ${ }^{3}$ opines, "For the first time in man's history, creation became totally and absolutely profane, providing natural sciences with its first and essential principle". This practical approach to matters of the physical world and the scientific attitude led them to explore the natural phenomenon, thereby paving the way for mankind to make progress in science and medicine.

1 Prof. M. M. Sharif., A History of Muslim Philosophy vol.1, (Royal Book Company, Karachi, 2007)

2 Philp. K. Hitti., History of the Arabs, $10^{\text {th }}$ ed. (London: Macmillan Education Ltd, 1970), 136.

3 Ismael. Raji. al-Faruqi, Historical Atlas of the Religions of the World. (New York: Macmillan Publishing Co. n.d), 246. 
Greaves, Zaller, Cannistraro and Murphey ${ }^{4}$ (n.d) honestly confess, "Perhaps the most influential Muslim intellectual contribution to the modern world however was science and medicine."

The period marked in Europe as the 'Dark Ages' is conversely regarded as 'the period of enlightenment' in the Muslim world. The reason is crystal clear; Muslims had the requisite morale, art and skill for the maximum utilization of both human capital and natural resources.

Over time, this enormous civilization witnessed many ups and downs. But when blind adherence to authority in place of reason together with internal strife, political unrest, and degeneration in Muslim society took impetus, it lured even the intruders (the Tatar invasion and the Fall of Baghdad) to give a final and decisive blow to crumple this once enormous civilization. The fate of the Muslim civilization bears testimony to the assertion of Hillarie Belloc ${ }^{5}$ when he said, "Men and nations fall by the same power as those by which they rise."

After the Fall of Baghdad in 1258 by Genghis Khan, except for some period under the Ottomans, the Muslim civilization went into quick recession. With the passage of time, ultimately this grand civilization degenerated into small, insignificant ethnic, racial, and geographical states subservient to colonialism.

In the later part of the $20^{\text {th }}$ century, colonialism also receded, at least apparently, and as a result now there are 57 predominantly Muslim states in the world. The Organization of Islamic Conference (OIC), comprising of 57 members states, is spread over four continents and defines itself as the collective voice of the Muslim world.

4 Richard. L, Greaves. Robert Zaller, Philip. V, Cannistraro Rhoads. Murphey, Harper and Row, Civilizations of the World: The Human Adventure, vol. A: To 1500, (New York Publishers, n.d.),136, 185.

5 Hilaire Belloc, The Sack of Rome. In M. A.Guy. Boas (Ed.) Modern English Prose (Lahore. Ferozsons Urdu Bazar, n.d.), 37. 


\section{CURRENT RESOURCES OF THE MUSLIM WORLD}

The 57-state Muslim world is endowed with natural and human resources, that have great potential for development. For the sake of clarity, these resources are discussed separately.

\subsection{Human Resources}

The Muslim world constitutes about " $23 \%$ of the world's total population." The ratio and percentage regarding population of the Muslim world is increasing with the passage of time and may cover up in the near future 1/4th of the world population. "Muslims who slowly but surely with a population approaching 1.5 billion people are climbing towards over a quarter of the world's population". ${ }^{6}$

According to United Nations Population Fund (UNFPA), "World Muslim Population Projection", the Muslim population was 361 million out of a total 2520 million world population in 1950. During the year 2000, it was 1209 million out of 6057 million of world population. The projected figure of the Muslim population for the year 2050 is 2588 million Muslim out of the total 9322 million population of the world.

\section{Table: Comparative Population of the Muslim World ${ }^{8}$}

\begin{tabular}{llllll}
\hline Population in millions & 1950 & 2000 & 2015 & 2025 & 2050 \\
World & 2520 & 6057 & 7207 & 7937 & 9322 \\
Muslims & 361 & 1209 & 1625 & 1921 & 2588
\end{tabular}

The world-wide data regarding population growth shows that Muslim community is rapidly bridging the number gap.

6 M. S. Karim, \& M. Khan, Muslim World Almanac 2008. Retrieved on 20th December, 2010 from http://star.com.jo/main/index.

7 United Nation Population Fund (n.d) World Muslim Population Projection Retrieved on $28^{\text {th }}$ December2010fromhttp://photius.com/rankings/muslim_populatoinprojections.html

8 Data Source: United Nations Population Fund (UNFPA). 


\subsection{Comparative Natural Resources of The Muslim World}

There are multiple natural resources available in the Muslim world. However, this investigation is focused upon the main resources, i.e., oil and gas, water, land chunk, water-straits and agriculture that are playing vital role in world economy.

\subsubsection{Oil and Gas}

Oil and gas are most sought after and expensive resources in the world. In this sphere, the Muslim world is ahead of all the nations of the world. It owns round about $75 \%$ of the total global oil reserves of the world. ${ }^{9}$ Furthermore, Muslim countries including Saudi Arabia, Iraq, Iran, Kuwait, the United Arab Emirates, Qatar, Yemen, Libya, Nigeria, Algeria, Kazakhstan, Azerbaijan, Malaysia, Indonesia, Brunei, possess between 66.2 to $75.9 \%$ of total oil reserves. The stronger position of the Muslim world regarding oil resources can be gauged from the comparative position of the world's only super power, the US which has barely $2 \%$ of total oil reserves. ${ }^{10}$ The share of Western countries is only $4 \%$ of total oil reserves. Michel Chossudovsky further states that only Iraq owns five times more oil than the United States and Muslim countries possess at least 16 times more oil than the Western countries.

The above-mentioned facts and figures are the real cause of the so-called "war on terrorism"- a plea on the basis of which the Western countries, especially the US and UK, try to snatch these oil and gas reservoirs from the Muslim countries. In the words of Michel Chossussdovsky, the US-led war in the broader Middle East, Central Asian region consists in gaining control over more than $60 \%$ of the world's reserves of oil and natural gas. ${ }^{11}$

The following table provides a clear picture of county-wide division of oil and gas around the world.

\footnotetext{
9 Michel Chossudovsky, The "Demonization" of Muslims and the Battle for Oil, (2007). http://www. martinfrost. ws/htmlfiles/ jan2007/ demonisation_oil.html (accessed December 12, 2010).

10 Ibid.

11 Ibid.
} 
Table: Oil Reserves by Country ${ }^{12}$

\begin{tabular}{|c|c|c|c|c|c|}
\hline \multirow[t]{2}{*}{ Country } & \multicolumn{5}{|c|}{$\begin{array}{l}\text { Year-wise Percentage of the Total Oil Reserves in } \\
\text { the World }\end{array}$} \\
\hline & 2006 & 2007 & 2008 & 2009 & 2010 \\
\hline Saudi Arabia & 21.85 & 21.67 & 20.42 & 19.78 & 18.01 \\
\hline Canada & 0.41 & 0.41 & 0.38 & 0.37 & 0.34 \\
\hline Iran & 11.44 & 11.35 & 10.70 & 10.36 & 9.43 \\
\hline Iraq & 9.51 & 9.43 & 8.89 & 8.61 & 7.84 \\
\hline Kuwait & 8.39 & 8.32 & 7.84 & 7.60 & 6.92 \\
\hline U.A.E & 8.09 & 8.02 & 7.56 & 7.32 & 6.67 \\
\hline Venezuela & 7.22 & 7.16 & 6.75 & 6.53 & 5.95 \\
\hline Russia & 6.56 & 6.50 & 6.13 & 5.94 & 5.41 \\
\hline Libya & 3.43 & 3.40 & 3.20 & 3.10 & 2.83 \\
\hline Nigeria & 3.08 & 3.05 & 2.88 & 2.78 & 2.54 \\
\hline U.S.A & 1.80 & 1.78 & 1.68 & 1.63 & 1.48 \\
\hline China & 1.29 & 1.28 & 1.21 & 1.17 & 1.06 \\
\hline Qatar & 2.16 & 2.15 & 2.02 & 1.96 & 1.79 \\
\hline Mexico & 1.06 & 1.05 & 0.99 & 0.96 & 0.88 \\
\hline Algeria & 1.01 & 1.00 & 0.94 & 0.91 & 0.83 \\
\hline Brazil & 1.01 & 1.00 & 0.94 & 0.91 & 0.83 \\
\hline Kazakhstan & 3.29 & 3.27 & 3.08 & 2.98 & 2.72 \\
\hline Norway & 0.71 & 0.70 & 0.66 & 0.63 & 0.58 \\
\hline Azerbaijan & 0.58 & 0.57 & 0.54 & 0.52 & 0.48 \\
\hline India & 0.47 & 0.47 & 0.44 & 0.43 & 0.39 \\
\hline Ecuador & 0.43 & 0.43 & 0.40 & 0.39 & 0.35 \\
\hline Indonesia & 0.36 & 0.36 & 0.34 & 0.33 & 0.30 \\
\hline U.K & 0.30 & 0.30 & 0.28 & 0.27 & 0.25 \\
\hline Egypt & 0.31 & 0.31 & 0.30 & 0.29 & 0.25 \\
\hline Malaysia & 0.44 & 0.44 & 0.41 & 0.40 & 0.37 \\
\hline Gabon & 0.17 & 0.16 & 0.15 & 0.15 & 0.14 \\
\hline Syria & 0.25 & 0.25 & 0.23 & 0.23 & 0.21 \\
\hline Argentine & 0.20 & 0.20 & 0.19 & 0.19 & 0.17 \\
\hline Columbia & 0.13 & 0.12 & 0.12 & 0.11 & 0.10 \\
\hline Vietnam & 0.27 & 0.27 & 0.25 & 0.24 & 0.22 \\
\hline Australia & 0.34 & 0.34 & 0.32 & 0.31 & 0.28 \\
\hline Brunei & 0.10 & 0.10 & 0.10 & 0.09 & 0.08 \\
\hline Denmark & 0.92 & 0.92 & 0.86 & 0.84 & 0.76 \\
\hline Peru & 1.01 & 1.00 & 0.94 & 0.91 & 0.83 \\
\hline Angola & 0.77 & 0.77 & 0.72 & 0.70 & 0.64 \\
\hline Oman & 0.46 & 0.46 & 0.43 & 0.42 & 0.38 \\
\hline Total Reserves of Muslim Countries & 73.74 & 73.15 & 68.94 & 66.77 & 60.82 \\
\hline Total Reserves of other Countries & 26.08 & 25.86 & 24.35 & 23.59 & 21.49 \\
\hline
\end{tabular}

12 Source: OPEC (2010/2011). Annual Statistical Bulletin. 


\subsubsection{Land Mass and Agriculture}

The Muslim world possesses a wide chunk of land mass on the surface of the globe. This land mass is of considerable variety covering arable and non-arable areas. It consists of a variety of forests.

As for agriculture, some Muslim countries like Pakistan, Bangladesh, Iran, Iraq, Turkey, Indonesia, Malaysia, etc., produce major agricultural products. Dates product is specific to Gulf countries. Strength in agriculture of the Muslim world can be imagined from the fact that the Islamic world's large footprint amounts to nearly 2935 million hectares; this represents some $22 \%$ of the world, 13392 million hectares, representing half of arable area. Of this area is about 2525.00 million hectares which represent approximately $4 \%$ of the arable area in the Islamic world. This means that there is a large amount of arable area, estimated 2572 million hectares are disabled, and could have a role in securing the Islamic world food need. ${ }^{13}$

\subsubsection{Water and Water Straits}

The Muslim world possesses a considerable share in global waters. It is situated almost in the middle sphere on the surface of globe covering both sides of the Tropic of Cancer. Most of the water straits and gulfs are situated in the said location. The gulfs and water straits to which the Muslim world has either control or access are the following: Black Sea, Caspian Sea, Red Sea, Persian Gulf, Mediterranean, Arabian Sea, Bay of Bengal, Java Sea, the Celebes Sea, Banda Sea, and the Strait of Gibraltar between Morocco and Spain, to name a few. If the Muslim world stands united, it could channelize unsuspecting trade and business routes in the world.

History of the Muslims reveals that when they were at the apex of civilization they were able to join together the far flung areas of the world. Kishlansky ${ }^{14}$ is perfectly right in saying that "by uniting the Mediterranean world with Arabia and India, Muslims created the greatest trade network the world had ever seen."

13 "The Problem of Poverty and Underdevelopment in the Islamic World" http://rawashdeh.ba7r.org/t266-topic (accessed on November 10, 2012)

${ }^{14}$ Patrick Geary, Mark Kishlansky, and O’Brien, Civilization in the West, Fourth edition, vol.1 (New York: Longman, n.d), 230. 
In an article titled 'a united Muslim world' by Mutahida Khilafat e Islami, the following facts about the Muslim world have been given:

- The largest population in the world, 1.6 billion

- Largest army in the world

- Control of half of the world's oil and many other natural resources

- Control of key strategic naval straits (a third of the world's oil travels through the straits of Hormuz which is between Iran and U.A.E) and air space

- Largest land mass

- Nuclear weapons ${ }^{15}$

\section{Weaknesses}

The Muslim world, despite being abundant in both natural and human resources, is still subjected to an utter state of confusion, unrest, poverty, illiteracy, political instability, low condition of human rights, marginalization, and 'demonization'. Mansoor Ali Khan ${ }^{16}$ has summarized, though in local context, such weaknesses by writing:

Unfortunately, vindictive conduct of elected governments, Martial Law (Dictatorship), feudalism, monopoly of certain families over industry, poor merchandize standards, unethical and dishonest trading practices, treating labor unjustly and inhumanly, corruption and social injustice are such aspects created by its own people that kept the economy of Pakistan from growing at its full potential." 17

Furthermore, he says, "....due to corrupt governments and mismanagement of natural funds, natural resources are not fully explored which has caused multiple problems at national level." ${ }^{\prime 18}$

\footnotetext{
15 “A United Muslim World” (MKI retrieved on $15^{\text {th }}$ Dec, 2010 from http://en-16 gb.facebook.com/note.php?note_id=150033068351885)

${ }^{16}$ Mansoor Ali Khan. Destiny of Mankind: Islam in the $21^{\text {st }}$ Century, (Al-Mansoor Publications, Upper Mall, Lahore), 149.

${ }^{17}$ Ibid.,149.

${ }^{18}$ Ibid., 181.
} 
However, this situation is rampant in nearly all Muslim countries. The following are the main weaknesses of the Muslim world:

- Lack of unity: Even in the presence of OIC the Muslims are unable to forge unity among the member states. There is a dearth of trust and brotherhood that has pulled apart the Muslim states.

- Deviation from the path of Islam: Muslims in general, have forgotten the true message and spirit of Islam. Islam believes in the sanctity of man's life, property and dignity but it has been localized, partly because of the political hegemony during colonialism by alien powers.

- Ignorance: Islam considers the acquisition of knowledge as the fundamental duty of every Muslim. ${ }^{19}$ But the recent scenario presents a very sad picture of the Muslim world regarding literacy rate and attainment of knowledge. Islam seems to have been limited to mere religious matters and its social aspect is ignored. Badawi, ${ }^{20}$ the Malaysian Prime Minister, has rightly asserted that limiting knowledge to religious matters and an overemphasis on rote learning extinguishes the spirit of discovery.

- Lack of Progress in Science and Technology: Lack of progress in science and technology in the Muslim countries is another weak point. According to Sawahel $^{21}$ "The 57 predominantly Muslim Countries have about $23 \%$ of the world's total population but less than $1 \%$ of its scientists who generate less that $5 \%$ of its science and make barely $0.1 \%$ of the world's original research discoveries each year", and, "Research and development manpower of Muslim countries is only $1.18 \%$ of the total science and technology manpower." ${ }^{22}$ In a report on Human Development in the Muslim World, Hady $\mathrm{Amr}^{23}$ has reported that Muslims constitute $22 \%$ of the world's population, almost $40 \%$ of the

19 The Holy Quran Sura Alaq, 96:4

${ }^{20}$ Badawi. 'Muslim Nations can Pursue Knowledge', 2008. Retrieved on December19th http://www.ft.com/cms

${ }^{21}$ Sawahel, W.A. IDBB Science Development Network (SDN) Present Development \& Future Prospects (2008). http//www. Sciencedev.net (accessed January 5, 2011).

${ }^{22}$ Ibid., 3.

${ }^{23}$ Hady Amr, "Human Development in the Muslim World," http://www.brookings.edu/papers/2008/02_islamic_world_amr.aspx (accessed on November 10, 2012 
world's out-of-school children are Muslims. This indication is sufficient to expose mismanagement of the human resources in the Muslim countries.

- Injustice: Injustice in its all forms and manifestations must be eradicated from the Muslim society. Currently, injustice reigns supreme in nearly all states of the Muslim world.

- Absence of Self Reliance: This is another major issue of the Muslim world. The Muslim world should strive to achieve self-reliance. It can be achieved through adopting proper mechanism for eradicating illiteracy, poverty, corruption, nepotism and the practice of marginalization.

- Lack of Mutual Trust: An environment of mutual trust is lacking among the 57 member states of OIC. The OIC cannot adopt a unanimous stance on nearly all international issues.

\section{Future Trends}

The gloomy picture of the Islamic world, despite being relatively dominant at present, is no doubt, one sided. There is a growing concern among the Muslim states, especially among the public, that we must stand united. To pursue this cherished goal, the OIC and the IDB (Islamic Development Bank) in particular are paying heed to this. The OIC has launched the well known TYPOA (Ten Years Program of Action). ${ }^{24}$

According to the IDB report on its role of IDB in promoting science and technology among the OIC member countries, 2010, the transnational cooperation among OIC member states is expressed in the following words:

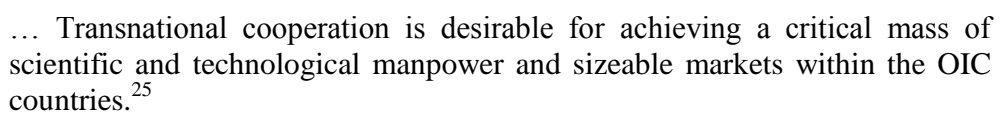

... Transnational cooperation is desirable for achieving a critical mass of scientific and technological manpower and sizeable markets within the OIC countries. ${ }^{25}$

In the same report, the IDB has reiterated support and cooperation for the general well-being of the Muslim world by establishing and strengthening the following policy initiatives:

\footnotetext{
${ }^{24}$ Islamic Development Bank. The Role of IDB in Promoting Science \& Technology in the OIC-member Countries, 2010, http//www.newsahead.com (accessed January 7, 2011), 3.

25 Ibid., 3.
} 
- The OIC Ten Year Program of Action (TYPOA)

- Promoting private sector investment in science and technology

- Self-reliance in vaccine production

- OIC vision $1441 \mathrm{H}$ for science and technology

- Islamic Academy of Sciences (IAS)

- Islamic Scientific, Educational \& Cultural Organization (ISESCO)

- African Center for Technology (ARCT)

- The Arab Science \& Technology Foundation (ASTF)

\section{Action Plan}

For the revival of progress and survival of the Muslim world, the following measures may be adopted on emergency basis:

- A strong conviction on the belief and knowledge system of Islam should be the foremost concern for the whole Muslim "Ummah". The new generation should be endowed with the true spirit of Islam. They may be enabled to understand and express in true sense the universality of Islam.

- Unity among Muslim countries may be ensured. The OIC may be, at least, internally strengthened and empowered from an 'Oh, I See' to a real Organization of Islamic Conference. If the whole Muslim world cannot be brought under the umbrella of a single leader, then, at least Military Alliance of Islamic Countries (MAIC), a NATO type body, may be established.

- Science and technology may be given priority in order to cope with the challenges of the $21^{\text {st }}$ century.

- An Islamic world think-tank may be established to deal primarily with the issues of future planning and pondering on strategic steps to be adopted for the well-being of Muslim 'Ummah'.

- Muslim specialists in all walks of life around the world should be pooled together for the development of the Muslim world.

- The Muslim countries should go for a joint venture in investment, trade and business. The free-trade policy may be adopted along with discarding visa restrictions. 
- A common currency like that of the Euro may be initiated.

- The Muslim world may focus on self reliance and mutual trust .

- Justice in all its dimensions be retained and maintained throughout the Muslim 'Ummah'.

- The Muslim world may establish Court of Muslim World for Conflict Resolution (CMWCR) for the resolution of intra and inter-state conflicts.

- By forging unity among the 57 member Muslim world and pooling their human and natural resources, the Muslim World may play her role for the establishment of global peace.

- Untrained and unemployed human resources are a sort of liability not an advantage; this is one of the major root causes of the misery of Muslim world. Therefore, last but not the least, Muslim world should create a common Human Resource Management Fund (HRMF) for the training and placement of human resources. 


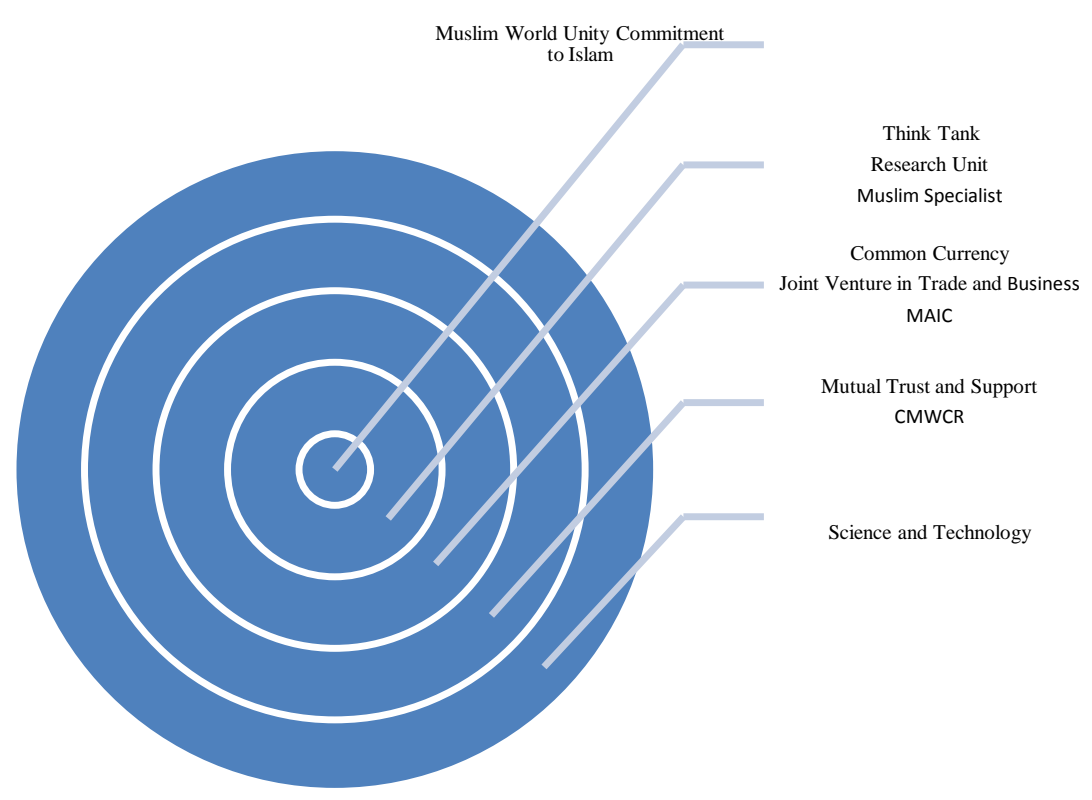

Figure 1: Model for Action Plan

\section{Abbreviation/Acronyms}

- CMWCR:

- MAIC:
Court for Muslim World for Conflict Resolution Military Alliance of Islamic Countries 


\section{SELECTED BIBLIOGRAPHY}

1. Al-Faruqi, Ismael Raji. Historical Atlas of the Religions of the World. New York: Macmillan Publishing Co., Inc. n.d.

2. Badawi, Abdullah Ahmad. "Muslim Nations can Pursue Knowledge" 2008. http://www.ft.com/cms/s/0/c78ff60e-c2c6-11dc-b6170000779fd2ac.html\#axzz2BsiNgnfU (Retrieved on December19th, 2010).

3. Belloc, Hilaire. The Sack of Rome. In M.A. Guy. Boas (Ed.) Modern English Prose, Ferozsons Urdu Bazar Lahore. n.d.

4. Chossudovsky, M. The "Demonization" of Muslims and the Battle for Oil, 2007. http://www.globalresearch.ca/the-demonization-of-muslims-and-thebattle-for-oil/4347 (Retrieved December 12, 2010)

5. Greaves, Richard. L, Robert Zaller, Philip Cannistraro, Murphey Rhoads. Civilization of the World: The Human Adventure, vol. A: To 1500, (New York: Harper and Row Publishers, 1990.

6. Hitti, P. K., History of the Arabs, $10^{\text {th }}$ ed. Macmillan Education Ltd., 1970.

7. Hady, Amr . A Report on Human Development in Muslim World, 2008. http://www.brookings.edu/research/papers/2008/02/islamic-world-amr (December 10, 2011).

8. Islamic Development Bank. The Role of IDB in Promoting Science \& Technology in the OIC-member Countries, 2010. from $\mathrm{http//www.newsahead.com,} \mathrm{(Retrieved} \mathrm{on} \mathrm{January} \mathrm{7,} 2011$ from January 1, 2011)

9. Karim, M.S. \& M. Khan, Muslim World Almanac, 2008. Retrieved on 20th December, 2010 from http://star.com.jo/main/index.

10. Kishlansky, Geary, and O'Brien. Civilization in the West, Fourth Edition, vol.1. New York: Longman, 1991.

11. Khan, Mansoor Ali. Destiny of Mankind: Islam in the $21^{\text {st }}$ century. Al-Mansoor publications, Upper Mall, Lahore, 2010.

12. OIC Organization of Islamic Conference Trade-system in Force, 2009.

Retrieved on January 1, 2011 from http//www.newsahead.com/preview/2009/01/01 Jeddah. 
Volume 2, Issue 1

Journal of Islamic Thought and Civilization

Spring 2012

13. Sharif, Prof. M.M. A History of Muslim Philosophy vol.1. Royal Book Company, Karachi, Pakistan, 2007.

14. Sawahel, W.A. IDBB Science Development Network (SDN) Present Development \& Future Prospects 2008, from http//www. Sciencedev.net. (Retrieved January 5, 2011) 